\title{
PARTIAL CHEMICAL CHARACTERIZATION OF ANTIGENIC PREPARATIONS OF CHROMOBLASTOMYCOSIS AGENTS
}

\author{
Tania Fraga BARROS(1) \& Maria Aparecida de RESENDE(2)
}

\begin{abstract}
SUMMARY
Antigenic preparations (saline, methylic, metabolic and exoantigens) of four agents of chromoblastomycosis, Fonsecaea pedrosoi, Phialophora verrucosa, Cladophialophora (Cladosporium) carrionii and Rhinocladiella aquaspersa were obtained. Partial chemical characterization of these antigenic preparations was obtained by determination of the levels of total lipids, protein, and carbohydrates, and identification of the main sterols and carbohydrates. Methylic antigens presented the highest lipid contents, whereas metabolic antigens showed the highest carbohydrate content. Total lipid, protein, and carbohydrate levels were in the range of 2.33 to $2.00 \mathrm{mg} /$ $\mathrm{ml}, 0.04$ to $0.02 \mathrm{mg} / \mathrm{ml}$ and 0.10 to $0.02 \mathrm{mg} / \mathrm{ml}$, respectively, in the methylic antigens and in the range of 0.53 to $0.18 \mathrm{mg} / \mathrm{ml}, 0.44$ to $0.26 \mathrm{mg} / \mathrm{ml}$, and 1.82 to $1.02 \mathrm{mg} / \mathrm{ml}$, respectively, in saline antigens. Total lipid, protein, and carbohydrate contents were in the range of 0.55 to $0.20 \mathrm{mg} / \mathrm{ml}, 0.69$ to $0.57 \mathrm{mg} / \mathrm{ml}$ and 10.73 to $5.93 \mathrm{mg} / \mathrm{ml}$, respectively, in the metabolic antigens, and in the range of 0.55 to $0.15 \mathrm{mg} / \mathrm{ml}, 0.62$ to $0.20 \mathrm{mg} / \mathrm{ml}$ and 3.55 to $0.42 \mathrm{mg} / \mathrm{ml}$, respectively, in the exoantigens. Phospholipids were not detected in the preparations. Saline and metabolic antigens and exoantigens presented hexose and the methylic antigen revealed additional pentose units in their composition. The UV light absorption spectra of the sterols revealed squalene and an ergosterol fraction in the antigens. The characterization of these antigenic preparations may be useful for serological evaluation of patients of chromoblastomycosis.
\end{abstract}

KEYWORDS: Chromoblastomycosis; Cladophialophora (Cladosporium) carrionii; Fonsecaea pedrosoi; Phialophora verrucosa; Metabolic antigen; Exoantigen.

\section{INTRODUCTION}

Chromoblastomycosis or dermatitis verrucosa is a chronic mycotic infection of man, usually limited to the skin and subcutaneous tissue $\mathrm{e}^{3,32}$, which primarily occurs in tropical and subtropical regions, among 30 to 50 years old men. The etiologic agents are traumatically introduced into the tissue, usually through occupational exposure. The lesions of chromoblastomycosis affect mainly the lower extremities. They begin as small erythematous papules that gradually enlarge to display varying morphologies such as verrucous nodules and cauliflower-like plaques ${ }^{30}$. The disease is caused by a variety of closely related pigmented fungi, which produce black or brown thick-walled spores in tissue and dark growths in culture. Five species of fungi are main causative agents of the disease: Fonsecaea pedrosoi, F. compacta, Phialophora verrucosa, Rhinocladiella aquaspersa and Cladophialophora (Cladosporium) carrionii $^{8,21,32}$.

The immunodiagnosis of the mycotic infections has been subject of many studies due to its sensitivity, providing positive results before the disease is revealed by culture and histopathology. It is, therefore, of great help in the diagnosis of this disease ${ }^{7}$. Serological evaluation of patients with chromoblastomycosis has not been used for diagnosis, probably due to either to lack of a suitable antigen with sensitivity and specificity or the fact that direct microscopical examination of clinical material is a rapid and reliable method for diagnosis of this infection $^{15,43}$.

Double immunodiffusion test has been used in the diagnosis of mycotic diseases. The method is efficient, not expensive and easily performed. However, sensitivity for detection of weakly reactive sera may be lacking. Complement fixation, on the other hand, is capable of detecting amounts of antibodies ${ }^{11}$.

The objectives of the present study were: 1) Obtaining of a simple and standardized methodology for preparation of one stable, sensible, and specific antigen of agents of chromoblastomycosis for later utilization in serological and immunodiagnosis studies; 2) Characterization of the antigenic preparations obtained by determination of the levels of total lipids, protein, and carbohydrates and identification of the main sterols and carbohydrates.

(1) Departamento de Microbiologia, Faculdade de Farmácia, Universidade Federal da Bahia, Salvador, BA, Brazil.

(2) Departamento de Microbiologia, Instituto de Ciências Biológicas da Universidade Federal de Minas Gerais, Belo Horizonte, MG, Brazil.

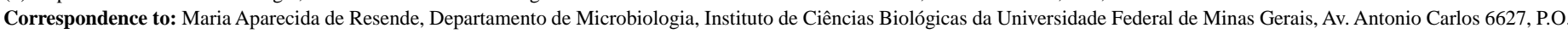
Box 486, 31270-901 Belo Horizonte, MG, Brazil. Phone: 5531 499-2760; Fax: 55 31 499-2730, E-mail: maresend@mono.icb.ufmg.br 


\section{MATERIAL AND METHODS}

\section{Microorganisms and culture media}

The strains of dematiaceous fungi were isolated from patients with chromoblastomycosis. Fonsecaea pedrosoi and Rhinocladiella aquaspersa were isolated from patients by OLIVEIRA et al. $(1977)^{29}$. F. pedrosoi was filed with the American Type Culture Collection (ATCC 46428). The other strains, $C$. carrionii (FMC 248), and $P$. verrucosa (FMC 2214) were obtained, from patients in Venezuela and kindly supplied by Dr. Dante Borelli. The medium used to maintain the microorganisms was Sabouraud Dextrose Agar (SDA). Transfers were done at 3-month intervals.

\section{Preparation of fungal cell mass}

The fungi were cultivated for 30 days on SDA slants on Petri dishes at $28^{\circ} \mathrm{C}$. The growth was harvested and homogenized in a tissue grinder and suspended in sterile $0.9 \% \mathrm{NaCl}$ solution. The suspension was cultivated in $250 \mathrm{ml}$ of Sabouraud Dextrose Broth for 30 days at $28{ }^{\circ} \mathrm{C}$ and shaken on a rotatory shaker for one hour each day. The cellular mass was harvested and centrifuged. Two percent of formaldehyde to a final proportion of 1:1 was added for obtaining methylic and saline antigenic preparations. The cellular mass was maintained at $-20{ }^{\circ} \mathrm{C}$ for 18 hours and then centrifuged three times with $0.9 \%$ sterile $\mathrm{NaCl}$ solution and was maintained at $-20{ }^{\circ} \mathrm{C}$ until the time for obtaining the antigenic preparations.

\section{Obtaining the antigenic preparations}

The methylic antigen was prepared according to technique previously described by CISALPINO et al. (1964) ${ }^{5}$ by adding $1.0 \mathrm{~g}$ of fungal cell mass to $100.0 \mathrm{ml}$ of methanol. Saline antigen was prepared by the method of OLIVEIRA $(1966)^{27}$ modified, and $10.0 \mathrm{~g}$ of cell mass were homogenized in a mortar for ten minutes and was suspended in $100 \mathrm{ml}$ of $0.9 \%$ sterile $\mathrm{NaCl}$ solution. Both methylic and saline antigens were maintained at $25^{\circ} \mathrm{C}$ for 10 days in dark flasks and then filtered through filter paper (Schleicher \& Schuell, No. 5892). The metabolic antigens were obtained by transferring $1 \mathrm{~g}$ of the homogenized fungal cell mass to $100 \mathrm{ml}$ of Smith medium ${ }^{37}$ and the suspension was cultivated at 28 ${ }^{\circ} \mathrm{C}$. After 15 days the growth was filtered through a Seitz filter according to technique of OLIVEIRA $(1966)^{27}$. The exoantigens were obtained according to the technique of ESPINEL-INGROFF et al. (1986) ${ }^{9}$. The fungi were grown on SDA slants for 10 days at $28^{\circ} \mathrm{C}$. After the incubation period the slants were covered with $10 \mathrm{ml}$ of sterile distilled water and left $24 \mathrm{~h}$ at $25^{\circ} \mathrm{C}$. The culture extracts were harvested, centrifuged, and treated with $0.5 \%$ of formaldehyde.

\section{Determinations of antigenic preparations dry weight}

Antigen aliquots of $0.5 \mathrm{ml}$ were dried at $80{ }^{\circ} \mathrm{C}$ until constant weight in previously weighed small aluminum containers. All experiments were done in triplicate.

\section{Chemical analysis}

The lipid fraction of the antigenic preparations was extracted with chloroform-methanol $(1: 1, \mathrm{v} / \mathrm{v})$ and purified with $0.88 \% \mathrm{KCl}$, according to the method of LETTERS (1968) ${ }^{18}$ modified by HUNTER \& ROSE $(1972)^{13}$. Total lipids were determined by dry weight, after vacuum evaporation. Phospholipids were tested by determination of phosphorus by technique of CHEN et al. (1956) ${ }^{4}$. Sterol analysis was performed after saponification according to the method of BREIVIK \& OWADES $(1957)^{2}$. The determination of total sterol content was tested as described by MOORE \& BAUMANN (1952) ${ }^{23}$. For sterol identification, the absorption spectra of the sterols were obtained, by the technique of KIM \& KWON-CHUNG (1974) ${ }^{16}$ in UV light region (220 to 310nm) using a Beckman (DB-GT) spectrophotometer. The protein content was determined by the method of LOWRY et al. $(1951)^{20}$. The total carbohydrate content was analyzed by the method of MORRIS (1948) ${ }^{24}$ utilizing the reagent of anthrone. The intensity of the green color produced by condensation of the anthrone reagent with the sugar derivates was measured in a spectrophotometer Micronal B 34211. The content of the carbohydrates was obtained by comparison of a standard curve of glucose. For qualitative analysis the absorption spectra of the solutions were obtained in a spectrophotometer in the visible light region (400 a 700nm) and compared with the absorption spectra of standard solutions of glucose, galactose, rhamnose, fructose, xylose, and ribose ${ }^{24}$.

\section{RESULTS AND DISCUSSION}

Tables 1, 2, 3, and 4 show the measurements of the methylic, saline, and metabolic antigens and exoantigens, respectively. The methylic antigens presented the highest percentage of lipids (82.27\%) (Table 1) while the saline, and metabolic antigens and the exoantigens had a higher carbohydrate content (Tables 2, 3, 4). The metabolic antigen, also called chromomycin ${ }^{28}$ and the exoantigen presented the highest percent contents of carbohydrates in the range of 18.53 to $32.84 \%$ and 48.43 to $11.44 \%$, respectively. Metabolic and exoantigens also presented the highest protein content $(0.69$ to $0.57 \mathrm{mg} / \mathrm{ml}$ and 0.62 to $0.20 \mathrm{mg} / \mathrm{ml}$ respectively). The lipid content of the metabolic antigens was closely similar to that of the exoantigens, 0.55 to $0.20 \mathrm{mg} / \mathrm{ml}$ and 0.55 to $0.15 \mathrm{mg} / \mathrm{ml}$, respectively.

The methylic antigens presented the higher lipid (82.27 to $63.48 \%)$ than protein or carbohydrates levels (Table 1), a fact possibly explained by the methodology employed to obtain the methylic antigens. The antigen was extracted with methanol. HAMDAN \& RESENDE (1988) ${ }^{12}$ demonstrated a higher percentage of lipids in methylic antigen obtained from a pool of Paracoccidioides brasiliensis strains (82.70\%) when compared with protein $(6.80 \%)$ and carbohydrates $(5.90 \%)$. CISALPINO $(1988)^{6}$ also obtained similar results with methylic antigen of the same fungus.

Lipids are the constituents of pathogenic fungi that are most correlated with pathogenicity ${ }^{31}$. SILVA \& EKIZLERIAN (1985) $)^{35}$ and SILVA \& FAZIOLI $(1985)^{36}$ reported that lipid extracts of $F$. pedrosoi, $F$. compacta, $P$. verrucosa, and $C$. carrionii induced pulmonary granulomatous reactions in mice and that lipids may possibly protect the microorganism against the defense mechanism of the host. GOMES \& RESENDE (1992) $)^{10}$ and SOARES et al. (1995) ${ }^{38}$ demonstrated, quantitated and partially characterized the lipids present in F. pedroso $i$ in conidiospores and in the filamentous phase.

The present result shows that the saline antigens obtained from different strains of chromoblastomycosis agents had low lipid levels 
Table 1

Dry weight and total lipids, protein, and carbohydrate contents $(\mathrm{mg} / \mathrm{ml})$ and percentage of the compounds of methylic antigens of chromoblastomycosis agents

\begin{tabular}{|c|c|c|c|c|c|}
\hline Strain & $\begin{array}{c}\text { Dry weight } \\
X^{\mathrm{a}} \pm \mathrm{s}^{\mathrm{b}}\end{array}$ & $\begin{array}{l}\text { Lipid (\%) } \\
\quad X \pm s\end{array}$ & $\begin{array}{c}\text { Protein }(\%) \\
\mathrm{X} \pm \mathrm{s}\end{array}$ & $\begin{array}{c}\text { Carbohydrate }(\%) \\
\mathrm{X} \pm \mathrm{s}\end{array}$ & $\begin{array}{c}\% \\
\text { Total }\end{array}$ \\
\hline F. pedrosoi & 2.670 .47 & $2.000 .00(74.91)$ & $0.03 \quad 0.01(1.12)$ & $0.10 \quad 0.01(3.74)$ & 79.77 \\
\hline P. verrucosa & $2.67 \quad 0.47$ & $2.330 .47(82.27)$ & $0.04 \quad 0.01(1.50)$ & $0.04 \quad 0.00(1.50)$ & 90.27 \\
\hline R. aquaspersa & $\begin{array}{ll}3.67 & 0.47\end{array}$ & $2.330 .47(63.48)$ & $0.03 \quad 0.00(0.82)$ & $0.07 \quad 0.01(1.90)$ & 66.20 \\
\hline C. carrionii & $3.00 \quad 0.82$ & $2.00 \quad 0.00(66.67)$ & $0.020 .00(0.67)$ & $0.020 .00(0.67)$ & 68.01 \\
\hline
\end{tabular}

${ }^{a}$ Average of at least three experiments

${ }^{\mathrm{b} S t a n d a r d ~ d e v i a t i o n}$

Table 2

Dry weight and total lipids, protein, and carbohydrate contents $(\mathrm{mg} / \mathrm{ml})$ and percentage of the compounds of saline antigens of chromoblastomycosis agents

\begin{tabular}{|c|c|c|c|c|c|}
\hline Strain & $\begin{array}{c}\text { Dry weight } \\
\mathrm{X}^{\mathrm{a}} \pm \mathrm{s}^{\mathrm{b}}\end{array}$ & $\begin{array}{l}\text { Lipid (\%) } \\
X \pm s\end{array}$ & $\begin{array}{c}\text { Protein }(\%) \\
X \pm s\end{array}$ & $\begin{array}{c}\text { Carbohydrate }(\%) \\
\mathrm{X} \pm \mathrm{s}\end{array}$ & $\begin{array}{c}\% \\
\text { Total }\end{array}$ \\
\hline F. pedrosoi & $31.67 \quad 1.25$ & $0.530 .19(1.68)$ & $0.380 .00(1.20)$ & $1.800 .25(5.68)$ & 8.56 \\
\hline P. verrucosa & 13.330 .47 & $0.33 \quad 0.02(2.50)$ & $0.360 .01(2.70)$ & $1.320 .10(9.90)$ & 15.10 \\
\hline R. aquaspersa & $12.67 \quad 1.70$ & $0.180 .06(1.44)$ & $0.260 .00(2.06)$ & $1.820 .16(14.34)$ & 17.86 \\
\hline C. carrionii & $31.67 \quad 1.25$ & $0.50 \quad 0.04(0.47)$ & $0.440 .01(1.39)$ & $1.020 .24(3.22)$ & 5.08 \\
\hline
\end{tabular}

${ }^{a}$ Average of at least three experiments

${ }^{\mathrm{b}}$ Standard deviation

Table 3

Dry weight and total lipids, protein, and carbohydrate contents $(\mathrm{mg} / \mathrm{ml})$ and percentage of the compounds of metabolic antigens of chromoblastomycosis agents

\begin{tabular}{|c|c|c|c|c|c|}
\hline Strain & $\begin{array}{c}\text { Dry weight } \\
X^{\mathrm{a}} \pm \mathrm{s}^{\mathrm{b}}\end{array}$ & $\begin{array}{c}\text { Lipid (\%) } \\
\mathrm{X} \pm \mathrm{s}\end{array}$ & $\begin{array}{c}\text { Protein }(\%) \\
\mathrm{X} \pm \mathrm{s}\end{array}$ & $\begin{array}{c}\text { Carbohydrate }(\%) \\
\mathrm{X} \pm \mathrm{s}\end{array}$ & $\begin{array}{c}\% \\
\text { Total }\end{array}$ \\
\hline F. pedrosoi & $32.67 \quad 2.36$ & $0.23 \quad 0.02(0.71)$ & $0.57 \quad 0.01(1.74)$ & $10.730 .19(32.84)$ & 35.29 \\
\hline P. verrucosa & $29.67 \quad 0.47$ & $0.250 .04(0.84)$ & $0.570 .00(1.92)$ & $8.60 \quad 0.28(28.98)$ & 31.74 \\
\hline R. aquaspersa & $33.00 \quad 1.63$ & $0.200 .04(0.63)$ & $0.590 .01(1.84)$ & $5.93 \quad 0.25(18.53)$ & 21.00 \\
\hline C. carrionii & $31.67 \quad 1.25$ & $0.550 .12(1.74)$ & $0.690 .00(2.18)$ & $8.43 \quad 0.24(26.62)$ & 30.54 \\
\hline
\end{tabular}

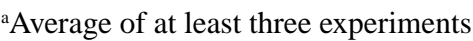

${ }^{\mathrm{b}}$ Standard deviation

Table 4

Dry weight and total lipids, protein, and carbohydrate contents $(\mathrm{mg} / \mathrm{ml})$ and percentage of the compounds of exoantigens of chromoblastomycosis agents

\begin{tabular}{|c|c|c|c|c|c|}
\hline Strain & $\begin{array}{c}\text { Dry weight } \\
\mathrm{X}^{\mathrm{a}} \pm \mathrm{s}^{\mathrm{b}}\end{array}$ & $\begin{array}{l}\text { Lipid (\%) } \\
\quad X \pm s\end{array}$ & $\begin{array}{c}\text { Protein }(\%) \\
X \pm s\end{array}$ & $\begin{array}{c}\text { Carbohydrate }(\%) \\
\mathrm{X} \pm \mathrm{s}\end{array}$ & $\begin{array}{c}\% \\
\text { Total }\end{array}$ \\
\hline F. pedrosoi & $\begin{array}{ll}7.67 & 0.47\end{array}$ & $0.15 \quad 0.05(1.19)$ & $0.20 \quad 0.00(2.61)$ & $1.280 .00(16.69)$ & 21.49 \\
\hline P. verrucosa & 3.670 .94 & $0.150 .00(4.01)$ & $0.21 \quad 0.01(5.72)$ & $0.42 \quad 0.22(11.44)$ & 21.17 \\
\hline R. aquaspersa & $\begin{array}{ll}4.67 & 0.94\end{array}$ & $0.17 \quad 0.04(3.58)$ & $0.30 \quad 0.01(6.42)$ & $1.75 \quad 0.23(37.47)$ & 47.47 \\
\hline C. carrionii & 7.330 .94 & $0.55 \quad 0.12(2.28)$ & $0.620 .03(8.45)$ & $3.550 .10(48.43)$ & 56.16 \\
\hline
\end{tabular}

${ }^{a}$ Average of at least three experiments

${ }^{\mathrm{b}}$ Standard deviation 
(Table 2). The percentage of these components ranged from $0.47 \%$ for the antigen obtained from $C$. carrionii to $2.50 \%$ for the antigen obtained from $P$. verrucosa. The carbohydrate fraction presented the highest percent value, ranging from $14.34 \%$ for the $R$. aquaspersa antigen to $3.22 \%$ for $C$. carrionii (Table 2). This result was expected since the antigenic components were extracted with physiological saline after rupture of the fungal cells. Among the substances measured (lipids, proteins and carbohydrates), carbohydrates presented higher solubility in aqueous solutions.

The metabolic antigens also presented larger amounts of carbohydrates compared to the other components, ranging from $32.84 \%$ for F. pedrosoi antigens to $18.53 \%$ for $R$. aquaspersa antigens (Table 3).

Among the components measured for the exoantigens, carbohydrates also prevailed, with levels ranging from $48.43 \%$ for $C$. carrionii to $11.44 \%$ for $P$. verrucosa (Table 4 ). These results were also expected since exoantigens seem to be found on the surface structure of the fungal wall. SZANISZLO et al. $(1972)^{41}$ reported that the presence of carbohydrates on the cell wall of chromoblastomycosis agents corresponds to one third of their dry weight. The same authors also stated that glucose is the major component of the cell wall of these agents and that the genera Fonsecaea, Phialophora and Cladosporium (Cladophialophora) have closely similar cell compositions mainly consisting of sugars, proteins and glucosamines. NEGRONI et al. $(1976)^{25}$ reported that paracoccidioidin contains polysaccharides as the major components. NOZAWA et al. (1971) ${ }^{26}$ observed that the polysaccharide fraction of dermatophytes is specific in skin tests as well as in other immunological reactions and suggested that this fraction may be the active principle of trichophytin.

On the other hand IBRAHIM-GRANET et al. $(1988)^{14}$, when characterizing $F$. pedrosoi antigens by immunoprecipitation, detected 13 types of antigens of different molecular weights and suggested that they were polypeptides.

Metabolic antigens were those presenting the highest dry weight values ( 33.0 to $29.26 \mathrm{mg} / \mathrm{ml}$ ), followed by saline antigens (31.67 to $12.67 \mathrm{mg} / \mathrm{ml})$ and exoantigens $(7.67$ to $3.67 \mathrm{mg} / \mathrm{ml})$ and finally by methylic antigens (3.0 to $2.67 \mathrm{mg} / \mathrm{ml}$ ) (Tables $1,2,3,4)$. These higher dry weight values for metabolic antigens may be related to the substances present in the culture medium used for strain growth and to obtain the antigen.

The absorption spectra of the standard carbohydrates showed that hexoses such as glucose, galactose, and fructose, presented a high peak on $625 \mathrm{~nm}$ while the pentoses ribose and xylose presented two peaks, one at $625 \mathrm{~nm}$ and the other at 500nm (Figure 1). Saline and metabolic antigens and exoantigens contain sugars, consisting of hexose units (Figure 1). In contrast, methylic antigens revealed the additional presence of pentoses. SOARES et al. (1995) ${ }^{38}$ reported that glucose, mannose, galactose, rhamnose, and glucosamine were detectable saccharide components of mycelium and conidia of $F$. pedrosoi. Polysaccharides, located on the outer layer of the cell wall are responsible for reactions with antibodies ${ }^{19}$, plant receptor lectins ${ }^{39,40}$ and bacterial fimbriae ${ }^{1,42}$.

The determination of total sterols ${ }^{23}$ could not be obtained in the antigens studied here because a final reading of the experiment was prevented by the interference of melanin. We believe that this substance, one of the chemical components of dematiaceous fungi ${ }^{33,34}$, was strongly solubilized in the solvents used for sterol extraction. Although the quantitative analysis of sterols was impaired, a qualitative analysis was performed. According to the UV light absorption spectra of the authentic sterols, ergosterol presented three peaks at 274, 283, and $298 \mathrm{~nm}$ (Figure 2). Lanosterol absorption showed two peaks at 228 and 248 and two minor peaks at 240 and $256 \mathrm{~nm}$. Squalene presented only one peak, at $228 \mathrm{~nm}$. The UV light absorption spectra of the non saponifiable fraction revealed the presence of a squalene-like sterol (absorption at $224 \mathrm{~nm}$ ) for all the antigens and methylic, saline, metabolic, and exoantigens, presented a peak at $274 \mathrm{~nm}$, relative to a first peak of ergosterol (Figure 2).

According to MEDOFF et al. $(1983)^{22}$, ergosterol is the major sterol detected in fungi. GOMES \& RESENDE (1992) ${ }^{10}$ detected ergosterol in cells of $F$. pedrosoi on the basis of UV absorption spectrum and thinlayer chromatography.

None of the antigens tested presented phospholipids in their constitution. GOMES \& RESENDE (1992) ${ }^{10}$ detected very low phospholipid values in $F$. pedrosoi cells. LESTER \& HANSON (1980) $)^{17}$ stated that the low phospholipid levels in fungi may be explained by the difficulty in their full extraction from fungal cells, or by the inefficiency of some methods in extracting all classes of phospholipids.

IWATSU et al. $(1982)^{15}$ prepared antigenic substances from culture filtrates of $F$. pedrosoi, P. verrucosa, Exophiala dermatitidis and E. jenselmei. These substances were evaluated as an antigen for detecting delayed hypersensitivity in-patients with chromoblastomycosis. More than half of the antigenic substances exhibited positive reactions only to antigens prepared from the homologous species. These results suggest that a delayed-type skin test using metabolic antigens may be useful not only for diagnosis of chromoblastomycosis but also for the identification of species of the causative agent.

To our knowledge, this is the first description of dematiaceous fungal antigens. The identification of these antigens may be useful for serological evaluation of chromoblastomycosis patients.

\section{RESUMO}

\section{Caracterização química parcial de preparações antigênicas de agentes da cromoblastomicose}

Preparações antigênicas (antígenos salinos, metílicos, metabólicos e exoantígenos) de quatro agentes da cromoblastomicose, Fonsecaea pedrosoi, Phialophora verrucosa, Cladophialophora (Cladosporium) carrionii e Rhinocladiella aquaspersa foram obtidos e foi determinada a caracterização química parcial dos mesmos. Os antígenos metílicos apresentaram os maiores teores de lípides enquanto os metabólicos os maiores teores em carboidratos. Lípides totais, proteína e carboidratos totais ocorreram na faixa de 2,33 a 2,00mg/ml, 0,04 a $0,02 \mathrm{mg} / \mathrm{ml}$ e 0,10 a $0,02 \mathrm{mg} / \mathrm{ml}$ respectivamente, nos antígenos metílicos e de 0,53 a $0,18 \mathrm{mg} / \mathrm{ml}, 0,44$ a $0,26 \mathrm{mg} / \mathrm{ml}$ e 1,82 a $1,02 \mathrm{mg} / \mathrm{ml}$ respectivamente, nos antígenos salinos. Lípides, proteínas e carboidratos totais ocorreram na faixa de 0,55 a $0,20 \mathrm{mg} / \mathrm{ml}, 0,69$ a $0,57 \mathrm{mg} / \mathrm{ml} \mathrm{e} 10,73$ a $5,93 \mathrm{mg} / \mathrm{ml}$ respectivamente, nos antígenos metabólicos, e na faixa de 0,55 a $0,15 \mathrm{mg} / \mathrm{ml}$, 

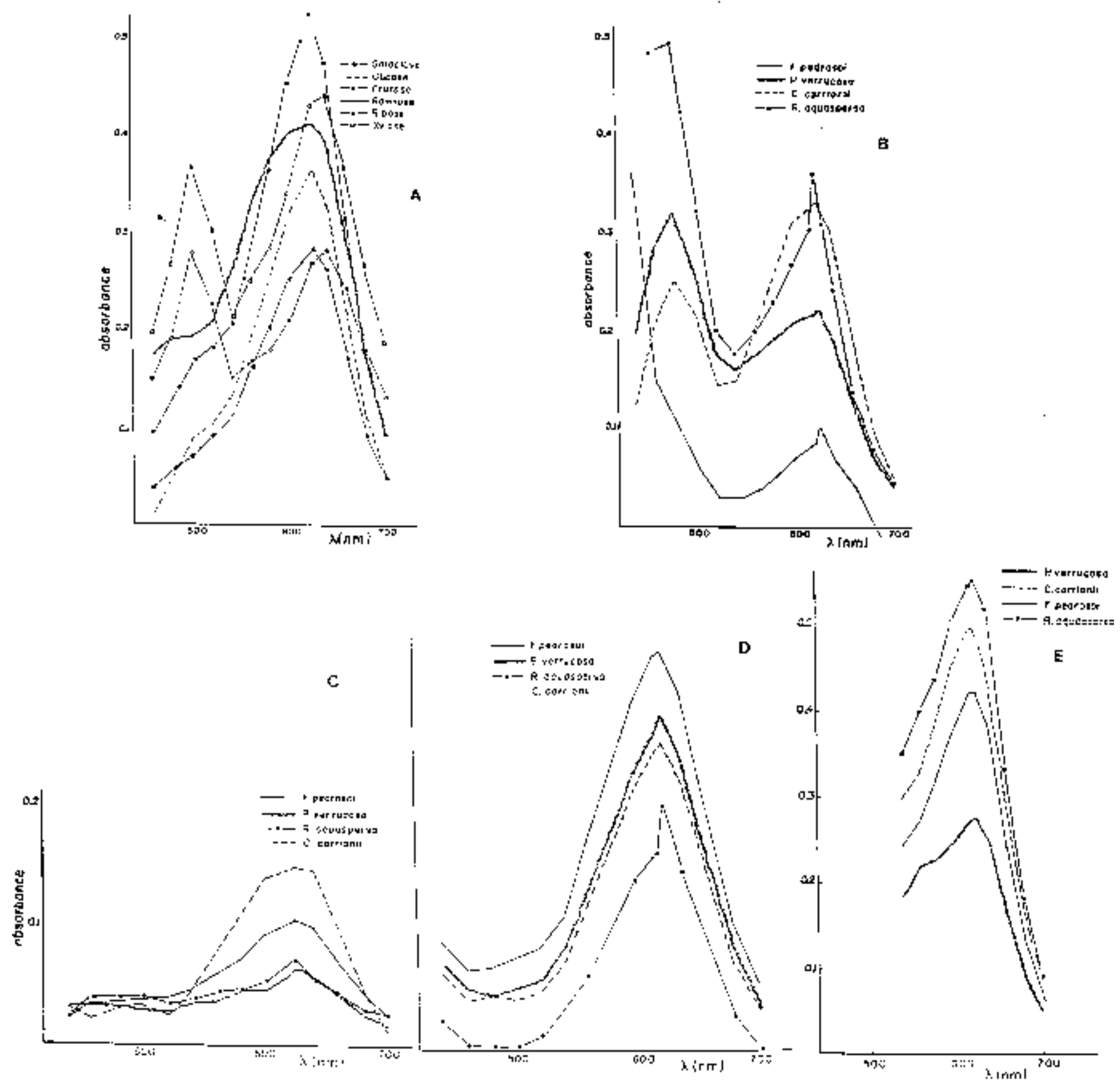

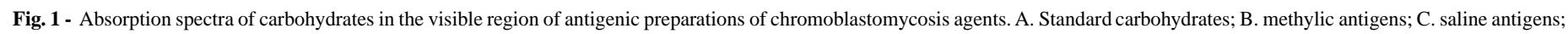
D. metabolic antigens; E. exoantigens. 

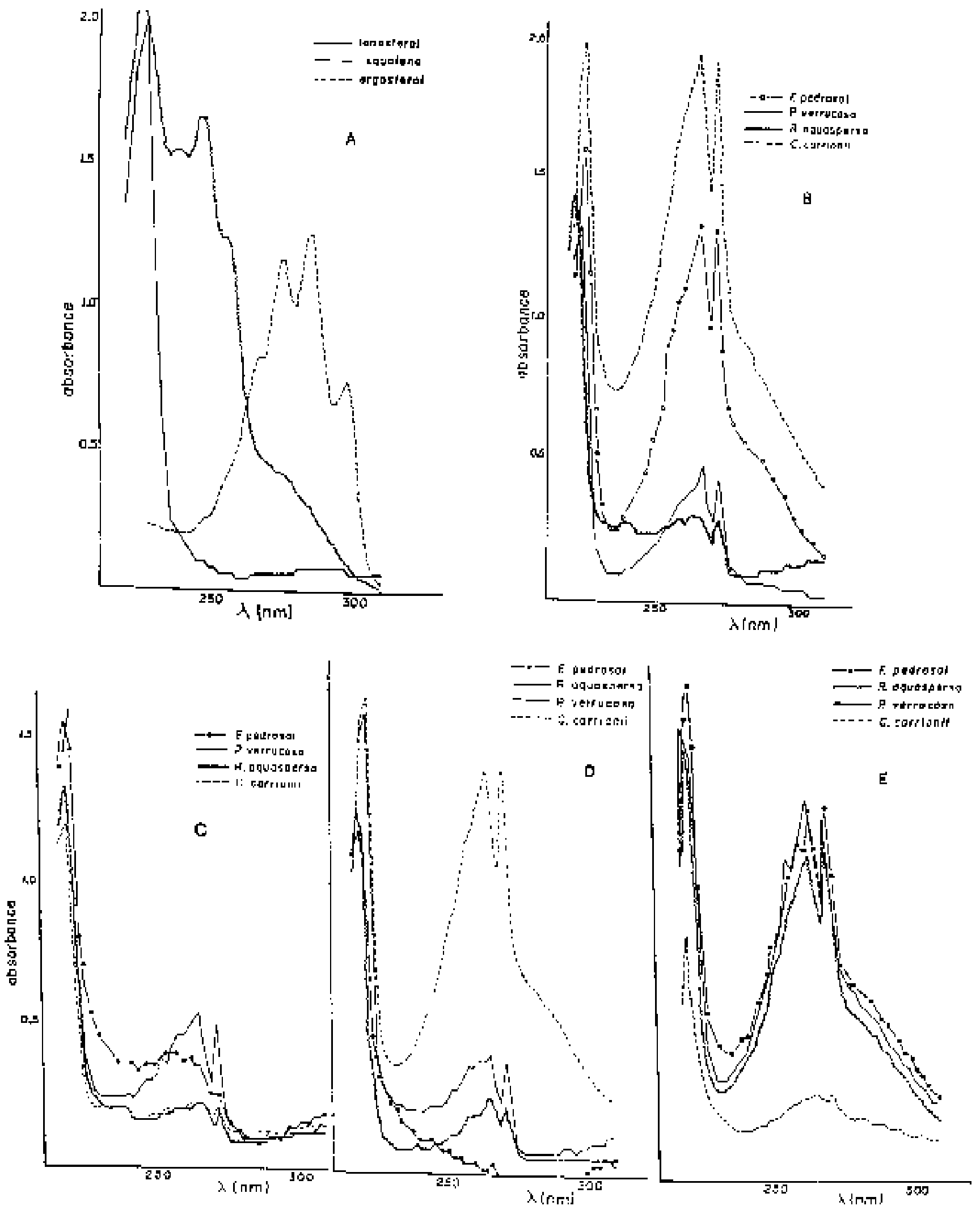

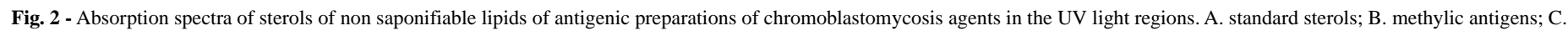
saline antigens; D. metabolic antigens; E. exoantigens. 
0,62 a $0,20 \mathrm{mg} / \mathrm{ml}$ e 3,55 a $0,42 \mathrm{mg} / \mathrm{ml}$ respectivamente, nos exoantígenos. Fosfolípides não foram detectados em nenhum dos antígenos. Os antígenos salinos, metabólicos e os exoantígenos apresentam hexoses enquanto os antígenos metílicos apresentam adicionalmente unidades de pentose em sua composição. $\mathrm{O}$ espectro de absorção na luz UV dos esteróis revelou esqualeno e ergosterol em todos os antígenos. A obtenção e caracterização química parcial desses antígenos poderá vir a ser de utilidade em estudos de sorologia de pacientes da cromoblastomicose.

\section{ACKNOWLEDGMENTS}

This work was supported by CNPq (Conselho Nacional de Desenvolvimento Científico e Tecnológico), CAPES (Coordenação de Aperfeiçoamento de Pessoal de Nível Superior), FAPEMIG (Fundação do Amparo a Pesquisa do Estado de Minas Gerais), and PRPq/UFMG (Pró-Reitoria de Pesquisas da Universidade Federal de Minas Gerais).

\section{REFERENCES}

1. ALVIANO, C.S.; GORIN, P.A.J. \& TRAVASSOS, L.R. - Surface polysaccharides of phytopathogenic strains of Ceratocystis paradoxa and Ceratocystis fimbriata isolated from different hosts. Exp. Mycol., 3: 174-187, 1979.

2. BREIVIK, O.N. \& OWADES, J.L. - Spectrophotometric semimicrodetermination of ergosterol in yeast. J. agric. Food Chem., 5: 360-363, 1957.

3. CARRION, A.L. - Chromoblastomycosis and related infections. Int. J. Derm., 14: 27 $32,1975$.

4. CHEN, P.S.; TORIBARA, T.Y. \& WARNER H. - Microdetermination of phosphorus Analyt. Chem., 28: 1756-1758, 1956.

5. CISALPINO, E.O.; OLIVEIRA, L.G. \& CARDOSO, J.P. - Experiência com um antígeno metílico no diagnóstico da blastomicose sulamericana. Arq. Cent. Estudo Fac. Odont. UFMG, 1: 117-121, 1964.

6. CISALPINO, P.S. - Sorodiagnóstico da paracoccidioidomicose através da reação de fixação do complemento com antígeno metílico de Paracoccidioides brasiliensis: comparação com as reações de imunofluorescência indireta e imunodifusão em gel de agarose. Belo Horizonte, 1988. (Dissertação de Mestrado - Instituto de Ciências Biológicas da Universidade Federal de Minas Gerais).

7. COOPER, B.H. \& SCHNEIDAU, J.D. - A serological comparison of Phialophora verrucosa, Fonsecaea pedrosoi and Cladosporium carrionii using immunodiffusion and immunoelectrophoresis. Sabouraudia, 8: 217-226, 1970.

8. DE HOOG, G.S.; GUÉRO, E.; MASCLAUX, F. \& VAN DEN ENDE, A H.G.G. Nutritional physiology and taxonomy of human-pathogenic Cladosporium-Xylohypha species. J. med. vet. Mycol., 33: 339-347, 1995.

9. ESPINEL-INGROFF, A.; SHADOMY, S.; DIXON, D. \& GOLDSON, P. - Exoantigen test for Cladosporium bantianum, Fonsecaea pedrosoi and Phialophora verrucosa. J. clin. Microbiol., 23: 305-310, 1986.

10. GOMES, M.H.R. \& RESENDE, M.A. - Fonsecaea pedrosoi: lipid composition and determination of susceptibility to amphotericin B. Canad. J. Microbiol., 38: 209$214,1992$.

11. GORDON, M.A.; ALMY, R.E.; GREENE, C.H. \& FENTON, J.W. - Diagnostic mycoserology by immunoelectrophoresis: a general, rapid and sensitive microtechnic. Amer. J. clin. Path., 56: 471-474, 1971.

12. HAMDAN, J.S. \& RESENDE, M.A. - Lipid composition and effect of amphotericin B on yeast cells of Paracoccidioides brasiliensis. Mycopathologia (Den Haag), 102: 97-105, 1988 .
13. HUNTER, K. \& ROSE A.H. - Lipid composition of Saccharomyces cerevisiae as influenced by growth temperature. Biochim. biophys. Acta (Amst.), 260: 639-653, 1972.

14. IBRAHIM-GRANET, O.; BIEVRE, C. \& JENDOUBI, M. - Immunochemical characterization of antigens and growth inhibition of Fonsecae a pedrosoi by speciesspecific IgG. J. med. Microbiol., 26: 217-222, 1988.

15. IWATSU, T.; MIYALI, M.; TAGUCHI, M. \& OKAMOTO, S. - Evaluation of skin test for chromoblastomycosis using antigen prepared from culture filtrates of Fonsecaea pedrosoi, Phialophora verrucosa, Wangiella dermatitidis and Exophiala jeanselmei. Mycopathologia (Den Haag), 67: 101-105, 1982.

16. KIM, S.J. \& KWON-CHUNG, K.J. - Polyene resistant mutants of Aspergillus fennelliae: sterol content and genetics. Antimicrob. Agents Chemother., 6: 102-113, 1974

17. LESTER, R.L. \& HANSON, B.A. - The extraction of inositol-containing phospholipids and phosphatidylcholine from Saccharomyces cerevisiae and Neurospora crassa. J. Lipid Res., 21: 309-314, 1980.

18. LETTERS, R. - Phospholipids of yeasts. In: Mills, A.E., ed. Aspects of yeast metabolism Oxford, Blackwell Science, 1968. p. 303-319.

19. LLOYD, K.O. \& TRAVASSOS, L.R. - Immunochemical studies on rhamno-D-mannans of Sporothrix schenckii and related fungi by use of rabbit human antisera. Carb. Res., 40: 89-97,1975.

20. LOWRY, O.H.; ROSEBROUGH, N.J.; FARR, A.L. \& RANDALL, R.J. - Protein measurement with Folin phenol reagent. J. biol. Chem., 193: 265-275, 1951.

21. MASCLAUX, F.; GUÉRO, E.; DE HOOG, G.S. \& CHRISTEN, R. - Phylogenetic relationships of human-pathogenic Cladosporium (Xylohypha) species inferred from partial LS rRNA sequences. J. med. vet. Mycol., 33: 327-338, 1995.

22. MEDOFF, G.; BRAJTBURG, J.; KOBAYASHI, G.S. \& BOLARD, J. - Antifungal agents useful in therapy of systemic fungal infections. Ann. Rev. Pharmacol. Toxicol., 23: 303-330, 1983.

23. MOORE, P.R. \& BAUMANN, C.S. - Skin sterols. I. Colorimetric determination of cholesterol and other sterols in skin. J. biol. Chem., 195: 615-621, 1952.

24. MORRIS, D.L. - Quantitative determination of carbohydrates with Dreywood's anthrone reagent. Science, 107: 254-255, 1948.

25. NEGRONI, R.; COSTA, M.R.I.G.; BIANCHI, O. \& GALIMBERTI, R. - Preparación y estudio de un antigeno celular de Paracoccidioides brasiliensis, util para pruebas cutaneas. Sabouraudia, 14: 265-273, 1976.

26. NOZAWA, Y.; NOGUCHI, T.; ITO, Y.; SUDO, N. \& WATANABE, S. - Immunochemical studies on Trichophyton mentagrophytes. Sabouraudia, 9: 129-138,1971.

27. OLIVEIRA, L.G. - Alguns aspectos imunológicos da cromomicose. Belo Horizonte 1966. (Tese de Doutoramento - Faculdade de Odontologia da Universidade Federal de Minas Gerais).

28. OLIVEIRA, L.G. - Isolamento e identificação dos agentes da cromomicose em Belo Horizonte. Rev. Soc. bras. Med. trop., 7: 7-10, 1972

29. OLIVEIRA, L.G.; RESENDE, M.A.; LOPES, C.F. \& CISALPINO, E.O. - Identificação de agentes da cromomicose. An. bras. Derm., 52: 1-5, 1977.

30. PASCHOAL, L.H.C. \& TAKAOKA, R. - Tratamento da cromomicose. Atualização terapêutica. Rev. bras. Clin. Terap., 12: 259-256, 1983.

31. PECK, R.L. - The lipids of fungi with special references to pathogenic fungi. In: NICKERSON, W.J., ed. Biology of pathogenic fungi. New York, Ronald Press, 1947. p. $162-188$

32. RIPPON, J.W. - Chromoblastomycosis. In: RIPPON, J.W., ed. Medical Mycology. The pathogenic fungi and the pathogenic actinomycetes. 3. ed. Philadelphia, WB Saunders, 1988. p. 276-296. 
33. SAN-BLAS, G. - The cell wall of fungal human pathogens: its possible role in host parasite relationships. Mycopathologia (Den Haag), 79: 159-184, 1982

34. SÄNCHEZ-MIRT, A.; ROMERO, H. \& FERNANDEZ-ZEPPENFELDT, G. - Growth and morphology of Cladophialophora (Cladosporium) carrionii. J. Mycol. méd., 7: 1-4, 1997.

35. SILVA, C.L. \& EKIZLERIAN, S.M. - Granulomatous reactions induced by lipids extracted from Fonsecaea pedrosoi, Fonsecaea compactum, Cladosporium carrionii and Phialophora verrucosa. J. gen. Microbiol., 131: 187-194, 1985.

36. SILVA, C.L. \& FAZIOLI, R.A. - Role of the fungal cell wall in the granulomatous response of mice to the agents of chromomycosis. J. med. Microbiol., 20: 299-305, 1985.

37. SMITH, C.E.; WHITING, E.G.; BAKER, E.E.; ROSEMBERGER, H.G. \& SAITO, M.T. - The use of coccidioidin. Amer. Rev. Tuberc., 57: 330-360, 1948.

38. SOARES, R.M.; ANGLUSTER, J.; SOUZA, W. \& ALVIANO, C.S. - Carbohydrate and lipid components of hyphae and conidia of human pathogen Fonsecaea pedrosoi. Mycopathologia (Den Haag), 132: 71-77, 1995.
39. SOUZA, E.T.; SILVA-FILHO, F.C. SOUZA, W et al - Identification of sialic acids on the cell surface of hyphae and conidia of the human pathogen Fonsecaea pedrosoi. J. med. vet. Mycol., 24: 145-153, 1986.

40. STROBEL, G.; VAN ALFEN, H.; HAPNER, K.D.; MCNINEIL, M. \& ALBERSHEIM, P. - Some phytotoxic glycopeptides from ceratocystis ulmi, the Dutch Elm disease pathogen. Biochim. Biophys. Acta, 538: 60-75, 1978.

41. SZANISZLO, P.J.; COOPER, B.H. \& VOGES, H.S. - Chemical compositions of the hyphal walls of three chromomycosis agents. Sabouraudia, 10: 94-102, 1972.

42. TRAVASSOS, L.R.; SOUZA, W.; MENDONÇA-PREVIATO, L. \& LLOYD, K.O. Location and biochemical nature of surface components reacting with concanavalin A in different cell types Sporothrix schenckii. Exp. Mycol., 1: 293-305, 1977.

43. VILLABA, E. \& YEGRES, J.F. - Detection of circulating antibodies in patients affected by chromoblastomycosis by Cladosporium carrionii using double immunodiffusion. Mycopathologia (Den Haag), 102: 17-19, 1988.

Received: 15 January 1999

Accepted: 25 October 1999 